\title{
Changes in Physicochemical and Sensory Qualities of "Goha" Strawberries Treated with Different Conditions of Carbon Dioxide
}

\author{
Dulal Chandra, Ae Jin Choi, Jung Soo Lee, Jinsu Lee, Ji Gang Kim \\ Postharvest Research Team, National Institute of Horticultural and Herbal Science, Rural Development \\ Administration, Suwon, Republic of Korea \\ Email: dchandrajp@gmail.com
}

Received 21 February 2015; accepted 6 March 2015; published 12 March 2015

Copyright (C) 2015 by authors and Scientific Research Publishing Inc.

This work is licensed under the Creative Commons Attribution International License (CC BY). http://creativecommons.org/licenses/by/4.0/

(c) (7) Open Access

\begin{abstract}
Harvested strawberry fruit is highly perishable because of its soft texture and microbial infestation during postharvest handling. The applications of carbon dioxide $\left(\mathrm{CO}_{2}\right)$ gas on the quality parameters of strawberry harvested in winter season have shown better effects in several studies. However, very little information is available for the same in summer harvested strawberry. This study was aimed at finding an optimum concentration and duration of $\mathrm{CO}_{2}$ treatment in strawberry fruit var. "Goha" harvested in summer season to increase or maintain postharvest qualities. Fresh strawberries were treated with $15 \%, 30 \%$ and $50 \% \mathrm{CO}_{2}$ for 1 or $3 \mathrm{~h}$ and then stored at $4{ }^{\circ} \mathrm{C}$ for up to 13 days along with untreated control. Strawberry samples treated with $50 \% \mathrm{CO}_{2}$ for 1 or $3 \mathrm{~h}$ and both $15 \%$ and $30 \%$ for $3 \mathrm{~h}$ had higher firmness than samples treated with both $15 \%$ and $30 \%$ for $1 \mathrm{~h}$ and control. In general, total soluble solids (TSS) slightly increased or maintained during storage in all samples except control. The values of $\mathrm{pH}$ slightly declined whereas titratable acidity showed opposite trends. However, there was no significant difference found among $\mathrm{CO}_{2}$ treated samples. Lightness $\left(L^{*}\right)$ of "Goha" samples with no $\mathrm{CO}_{2}$ treatment decreased gradually while it was almost maintained in $\mathrm{CO}_{2}$ treated strawberries. Strawberry samples treated with $15 \%$ $\mathrm{CO}_{2}$ for $3 \mathrm{~h}$ maintained better quality with higher scores of overall quality and visual texture until 9 days of storage. Samples treated with $15 \% \mathrm{CO}_{2}$ for $3 \mathrm{~h}$ also received lower softening scores until 9 days of storage compared to other $\mathrm{CO}_{2}$ treated samples. These results showed that $15 \% \mathrm{CO}_{2}$ for 3 $h$ condition could be an effective postharvest treatment for maintaining quality of "Goha" strawberry.
\end{abstract}

\section{Keywords}

Carbon Dioxide, Firmness, Quality, Strawberry, Storage

How to cite this paper: Chandra, D., Choi, A.J., Lee, J.S., Lee, J. and Kim, J.G. (2015) Changes in Physicochemical and Sensory Qualities of "Goha" Strawberries Treated with Different Conditions of Carbon Dioxide. Agricultural Sciences, 6, 325-334. 


\section{Introduction}

Strawberry (Fragaria $\times$ ananassa Duch.) is a non-climacteric fruit with a very short postharvest life. It is highly perishable, being susceptible to mechanical injury, desiccation, water loss, microbial decay and physiological disorders during postharvest handling such as transportation and storage. The main characteristics related to the quality of ripened strawberry fruit are texture, flavour (soluble sugars and organic acids) and color (anthocyanin content). Generally, loss of quality is mostly occurred due to its relatively high metabolic activity and sensitivity to fungal decay. Change in texture is a consequence of the natural process of senescence and also of the atmosphere in which the fruits are stored. Besides, the obvious changes in appearance, mold contamination can also promote undesirable changes in texture and contribute to reduced strawberry shelf-life. Hence, various kinds of physical or chemical methods have been applied to improve the postharvest shelf-life of strawberries.

The storage life of some horticultural produces has shown to be prolonged through the reduction in respiration and other metabolic reactions and a decrease in decay by the alterations in the concentrations of oxygen $\left(\mathrm{O}_{2}\right)$ and carbon dioxide $\left(\mathrm{CO}_{2}\right)$ where they are stored. Carbon dioxide is a common, available and non-toxic gas that has been used in many postharvest operations to extend or improve their postharvest life and/or quality. Several studies have shown that $\mathrm{CO}_{2}$-enriched atmospheres could extend the storage life of strawberry by inhibiting fruit softening and decay [1] [2]. However, the high $\mathrm{CO}_{2}$ concentrations to maintain strawberry qualities are often too close to the level of fruit tolerance, and some adverse effects have been reported [3] [4]. Higher $\mathrm{CO}_{2}$ levels can also cause an accumulation of fermentation products that negatively affect fruit acceptability [5]. On the other hand, short-term high- $\mathrm{CO}_{2}$ treatments have also been used as postharvest elicitors to induce the synthesis of phytochemicals and/or beneficial changes in composition affecting quality traits such as deastringency in persimmons [6] [7]. In case of strawberry, an increase in fruit firmness was observed when fruits are exposed to a short-term flush of $100 \mathrm{kPa} \mathrm{CO}_{2}$ [8] [9].

Being a good source of nutrients and vitamins, strawberry is used in different purposes which make it a most versatile fruit. Strawberries can be eaten fresh, cooked or frozen too. The demand of strawberries has been increased and growers and researchers have attempted to produce strawberry all year round in Korea. Production of strawberry varieties developed in Korea has increased with higher potential for export to other countries. The "Goha" strawberry is a new cultivar in Korea, which was developed from a cross between "Elan” and "Flamingo" and now successfully grown in summer with high fruit quality [10].

Assessment of strawberry quality for the market is focused on visual and internal characteristics, such as size, color, firmness, acidity, sweetness and aroma [11] [12]. Firmness of strawberry is not only important for their eating quality but also for their shipping ability. Soft fruits cannot be shipped over long distances without substantial losses due to physical injuries. Therefore, the increment in firmness quality of strawberry is a pivotal aspect for postharvest handling, especially for export oriented strawberries. Previous studies have shown that fruit firmness is affected by cultivars, fruit maturity, temperature and length of $\mathrm{CO}_{2}$ treatment during storage of strawberry [8] [13] [14]. However, little information is available on the effect of postharvest $\mathrm{CO}_{2}$ application on the firmness and other quality parameters of "Goha” strawberry. Hence, the objectives of this study were to investigate the effects of different concentrations and times of short-term $\mathrm{CO}_{2}$ application on the firmness and quality of "Goha” strawberry as well as find out an appropriate method for $\mathrm{CO}_{2}$ treatment in this variety.

\section{Material and Methods}

\subsection{Plant Materials and Treatments}

Fresh strawberries (Fragaria $\times$ ananassa Duch. cv. Goha) with red color on $70 \%$ - 80\% of the fruit surface were hand-harvested from a commercial firm in Muju, Republic of Korea. Strawberry fruits were freshly harvested in the early morning and immediately transported to the postharvest laboratory of National Institute of Horticultural and Herbal Science, Suwon by a refrigerated truck maintaining a temperature of $4^{\circ} \mathrm{C}$. Fruits were graded for uniformity of color and size, and damaged fruits were removed. About $300 \mathrm{~g}$ fruits were then placed in transparent plastic box $(16 \times 12 \times 8 \mathrm{~cm})$ with several holes on the top and bottom portion of the box. One box of strawberry was considered as one replicate and four replicates were used in each treatment. Strawberry boxes were subjected to different concentrations and time of $\mathrm{CO}_{2}$ treatment using acrylic chamber $(60 \times 30 \times 30 \mathrm{~cm})$ and $\mathrm{CO}_{2}$ cylinder attached to a pressure gauge and a gun-like injector. Strawberries were treated with air (control), $15 \% \mathrm{CO}_{2}$ gas for 1 or 3 hours (15\% $\mathrm{CO}_{2}-1$ h or $\left.15 \% \mathrm{CO}_{2}-3 \mathrm{~h}\right), 30 \% \mathrm{CO}_{2}$ gas for 1 or 3 hours $\left(30 \% \mathrm{CO}_{2}-1\right.$ h or $\left.30 \% \mathrm{CO}_{2}-3 \mathrm{~h}\right), 50 \% \mathrm{CO}_{2}$ gas for 1 or 3 hours $\left(50 \% \mathrm{CO}_{2}-1 \mathrm{~h}\right.$ or $\left.50 \% \mathrm{CO}_{2}-3 \mathrm{~h}\right)$ and stored at $4{ }^{\circ} \mathrm{C}$ for up to 13 
days. Strawberry boxes were placed in the chamber, tightened the chamber opening and $\mathrm{CO}_{2}$ was supplied to the chamber using small holes of the chamber where $\mathrm{CO}_{2}$ concentration was monitored with a gas analyzer. The treatments were conducted at room temperature and when $\mathrm{CO}_{2}$ concentration reached at expected level in different treatments, the chamber was completely closed and transferred to $4{ }^{\circ} \mathrm{C}$ storage room. After stipulated treatment duration, the chambers were taken out from the storage room, opened and only strawberry boxes were immediately transferred to $4^{\circ} \mathrm{C}$ storage room. Evaluations of sensory, physical and biochemical qualities were carried out on $0,3,6,9$ and 13 days of storage.

\subsection{Color and Texture Measurement}

Surface color of randomly selected seven fruit from each replicate was measured using a colorimeter (CR-400 Minolta, Osaka, Japan) which provided CIE $L^{*}, a^{*}$ and $b^{*}$ values. Measurements were taken from opposite sides around the equatorial zone of the fruit. The meter was calibrated using the manufacturer's standard white plate (Y 93.5, x 0.3155, y 0.3320). $L^{*}$ refers to the lightness and ranges from black $=0$ to white $=100$. A negative value of $a^{*}$ indicates green, while a higher positive number indicates red color. Positive and negative $b_{1 / 2}^{*}$ indicate yellow and blue color, respectively. These values were then converted into chroma $\left\{C^{*}=\left(a^{* 2}+b^{* 2}\right)^{1 / 2}\right\}$, which indicates the intensity or color saturation.

The firmness was measured using a texture analyzer (TA Plus, Lloyd Instruments, Ametek Inc., UK) fitted with a flat probe. Each fruit was placed horizontally on the stationary platform and compressed $8 \mathrm{~mm}$ at a rate of 5,2 and $10 \mathrm{~mm} \cdot \mathrm{s}^{-1}$ as the pre-test, test and post-test speed, respectively. With a running load cell of $20 \mathrm{~N}$, the probe was attached to a creep meter equipped with the software (NEXYGEN ${ }^{\mathrm{TM} M T} \mathrm{v} 4.5$, Lloyd Instruments, Ametek Inc., UK) for automatic analysis using a computer. The maximum force (N) developed during the test was recorded. Eight strawberry fruit from each replicate were randomly selected and a total of 32 data from four replicates were averaged from each treatment. All measurements were taken at room temperature $\left(20^{\circ} \mathrm{C} \pm 2^{\circ} \mathrm{C}\right)$.

\subsection{Determination of Total Soluble Solids, $\mathrm{pH}$, and Titratable Acidity}

Total soluble solid (TSS), pH and titratable acidity (TA) were measured according to the AOAC [15] procedures. On each evaluation day, 3 - 5 fruit from each replicate was wrapped with 2 layers of cotton cloth and squeezed with a hand pressed juice maker. TSS of the resultant juice was measured in terms of brix using a refractometer (PAL-1, Atago Co. Ltd, Tokyo, Japan). The $\mathrm{pH}$ was determined using a $\mathrm{pH}$ meter (D-55122, Schott Instruments GmbH, Germany) with a glass electrode. Titratable acidity was measured by diluting each $5 \mathrm{~mL}$ aliquot of strawberry juice in $20 \mathrm{~mL}$ distilled water and then titrating to $\mathrm{pH} 8.2$ using $0.1 \mathrm{~N} \mathrm{NaOH}$ and finally the results were expressed as percentage of citric acid.

\subsection{Sensory Evaluation}

The sensory analysis of strawberry sample was carried out by an 8-member (aged 24 - 48) expert panel. The members of the panel were trained to recognize and score overall visual quality, appearance, visual texture, of strawberry sample prior to the test. These sensory qualities were evaluated by using 9 -point scale $(9=$ excellent, 7 = good, 5 = fair, 3 = poor and 1 = unusable). A score of 6 was considered as the limit of marketability. Softening score of individual fruit in a box was carried out on a 0 - 4 scale, where $0=$ normal ( $0 \%$ surface softened), $1=$ trace (up to $10 \%$ surface softened), 2 = slight (10 to $25 \%$ surface softened), $3=$ moderate $(25 \%-50 \%$ surface softened), and $4=$ severe ( $>50 \%$ surface softened). Softening index was then calculated from the following formula

$$
\text { Softening index }=\frac{\text { Total softening score received in a box }(\text { fruit } \times 0+\text { fruit } \times 1+\text { fruit } \times 2+\text { fruit } \times 3+\text { fruit } \times 4)}{\text { Maximum possible score in a box }(\text { total fruit } \times 4)}
$$

\subsection{Statistical Analysis}

The experiment was conducted with four replications per treatment. Statistical analyses of the data were carried out using SAS software (SAS Institute, Cary, NC, USA). The level of significance was calculated from the $F$ value of ANOVA. Mean comparison was achieved by Duncan's multiple range test. Prior to the final experiment, two preliminary experiments were conducted with limited replications that resulted similar trend. 


\section{Results and Discussion}

\subsection{Changes in Firmness}

After treated with $\mathrm{CO}_{2}$ gas, strawberry fruit firmness increased in all longer duration treatments and both of $50 \%$ $\mathrm{CO}_{2}$ treatment (Figure 1). Sharp increases in firmness were observed in $50 \% \mathrm{CO}_{2}$ treated strawberry, whereas slight increase were found in strawberry samples treated with $15 \%$ and $30 \% \mathrm{CO}_{2}$ for $3 \mathrm{~h}$. At the beginning of storage, fruit firmness increased in all samples except $50 \% \mathrm{CO}_{2}$ treatment. Firmness of $15 \% \mathrm{CO}_{2}-3 \mathrm{~h}$ increased gradually and both of $30 \% \mathrm{CO}_{2}$ treated samples increased until 6 days of storage and then declined slightly or just maintained. Although increases in fruit firmness were reported in few studies by the application of $\mathrm{CO}_{2}$ [14] [16], our results revealed that time of treatment and concentration greatly affect the firmness of studied strawberry variety. Matsumoto et al. [14] also reported that the magnitudes of the increases in fruit firmness were different among cultivars and principally due to a shift toward significantly greater abundance of chelator-associated pectins at the expense of water- and alkali-soluble pectins. Furthermore, significant increase in chelatorsoluble polymers and a concomitant decrease in water-soluble polymers were reported in skin and flesh tissues of strawberries exposed to high $\mathrm{CO}_{2}$ environment [8] [16]. The increasing pattern of firmness at the end of storage could be a consequence of water loss (data not shown) from the surface of fruit that made it farmer. However, we recorded significant decline in other parameters like sensory qualities (discussed later) on 13 days and hence, firmness measured instrumentally was less evident on this day.

\subsection{Total Soluble Solids, pH, Titratable Acidity and Color}

Total soluble solid of control sample declined throughout the storage whereas it slightly increased or maintained in $\mathrm{CO}_{2}$ treated samples (Figure 2). However, all samples treated with $\mathrm{CO}_{2}$ for longer duration showed a sudden decline on 3 days of storage and the TSS were recovered thereafter. Overall, $\mathrm{CO}_{2}$ treated samples exhibited higher TSS compared to untreated control sample. Among the $\mathrm{CO}_{2}$ treated samples, TSS of $15 \% \mathrm{CO}_{2}-3 \mathrm{~h}$ treatment increased insignificantly until the end of storage while TSS of $30 \% \mathrm{CO}_{2}-1 \mathrm{~h}$ treatment declined gradually though higher values were recorded at the beginning of storage. Although Pelayo-Zaldivar et al. [17] found reduced TSS in strawberry stored in air or air $+20 \mathrm{kPa} \mathrm{CO}_{2}$ environment for 3 and 6 days, Blanch et al. [18] reported the highest accumulation of total sugar was occurred when strawberries were exposed to a continuous gas mixture containing $20 \% \mathrm{CO}_{2}+20 \% \mathrm{O}_{2}+60 \% \mathrm{~N}_{2}$. Gil et al. [1] found slight decline in TSS after 5 days in strawberries stored in air and after 10 days in different concentration of $\mathrm{CO}_{2}$ enriched environment. Unlike TSS, $\mathrm{pH}$ was lightly affected by $\mathrm{CO}_{2}$ treatment and we found little decline in $\mathrm{pH}$ after $\mathrm{CO}_{2}$ treatment (Figure 2).

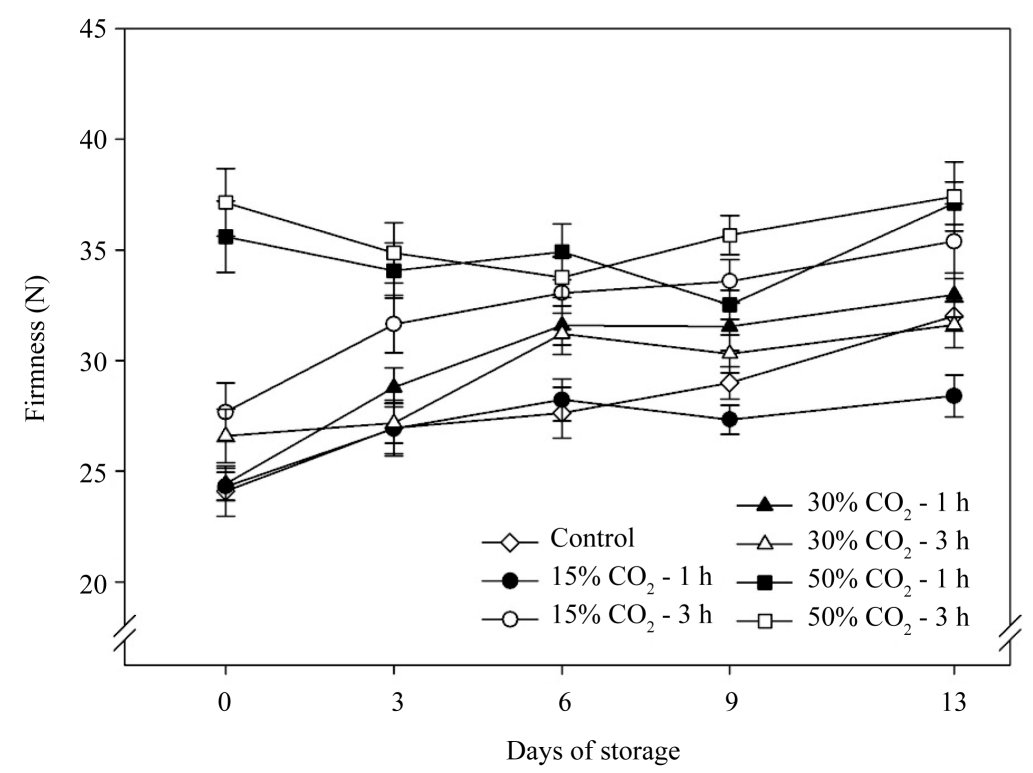

Figure 1. Changes in firmness of "Goha" strawberry treated with different conditions of $\mathrm{CO}_{2}$ during storage at $4^{\circ} \mathrm{C}$. 

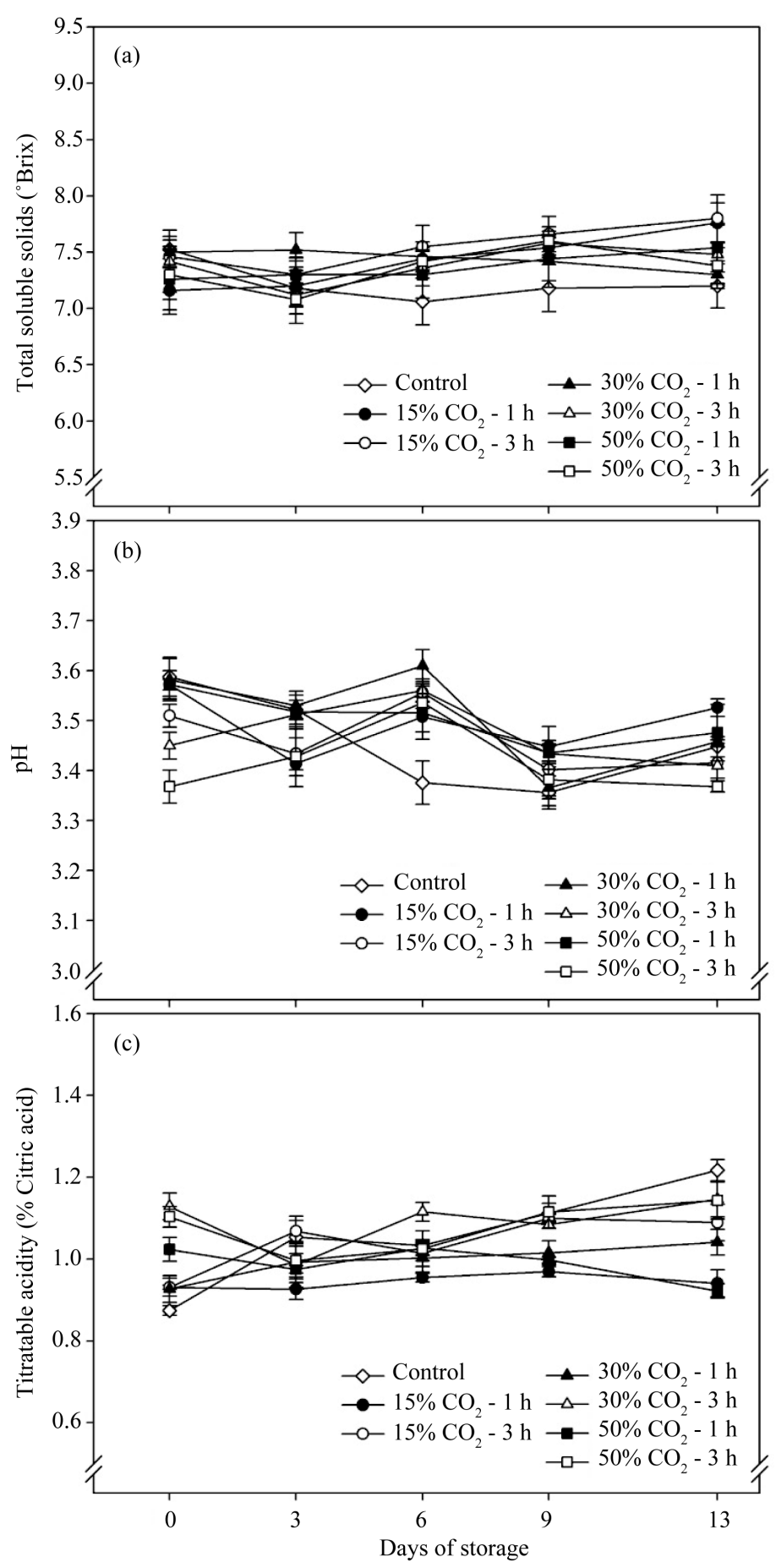

Figure 2. Changes in total soluble solids (a), $\mathrm{pH}$ (b) and titratable acidity (c) of "Goha" strawberry treated with different conditions of $\mathrm{CO}_{2}$ during storage at $4^{\circ} \mathrm{C}$.

However, sample treated with $30 \%$ and $50 \% \mathrm{CO}_{2}$ for 3 h showed significant decline $(\mathrm{p}<0.05)$ in $\mathrm{pH}$ compared to control sample on treatment day. Overall, $\mathrm{pH}$ of $\mathrm{CO}_{2}$ treated samples did not show significant variation ( $>$ 0.05) either among them or in between storage days which is in consistent with the results of Gil et al. [1] on strawberries stored in different concentration of $\mathrm{CO}_{2}$ enriched environments. Similarly, Pelayo-Zaldivar et al. [17] observed no specific trend in $\mathrm{pH}$ of strawberry during storage at elevated $\mathrm{CO}_{2}$. 
Titratable acidity, on the other hand, slightly increased by $\mathrm{CO}_{2}$ treatment and $30 \% \mathrm{CO}_{2}-3 \mathrm{~h}$ and both of $50 \%$ $\mathrm{CO}_{2}$ treatments showed greater increase $(\mathrm{p}<0.05)$ in TA compared to control or other treatments (Figure 2). However, TA values of shorter duration $\mathrm{CO}_{2}$ treated samples declined slightly or maintained until the end of storage whereas these values were slightly increased at the end of storage in samples treated with $\mathrm{CO}_{2}$ for longer duration. Unlikely, Gil et al. [1] found insignificant decline in TA in "Selva" strawberries stored at $40 \% \mathrm{CO}_{2}$. It was reported that the changing pattern of TSS, $\mathrm{pH}$ and TA are variable depending on the many factors such as cultivars, growing seasons, cultivation methods and nutrient supply as well as postharvest handling including storage condition [1] [17]-[19]. "Goha" strawberry is a new cultivar in Korea and usually grown in summer season which might have unique physio-biochemical characteristics and probably thereby response in a differently way to that of other cultivars in respect to $\mathrm{CO}_{2}$ treatments reported by various researchers. The initial TA of this strawberry was $0.87 \%$ whereas TA of $15 \%, 30 \%$ and $50 \% \mathrm{CO}_{2}$ for $3 \mathrm{~h}$ treated samples were $0.93,1.13$ and $1.10 \%$, respectively. In an earlier study, Shin et al. [19] reported $0.79 \%$ TA of "Goha" strawberry which was nearly similar to our result. The slight decline in TA of strawberry during storage could be due to the further ripening of the fruit and in consistent with those reported by Han et al. [20] and Shin et al. [19].

Since color is the most important factor affecting the overall quality and appearance of strawberry, we measured surface color using Hunter color spaces. It revealed that color parameters were less affected by $\mathrm{CO}_{2}$ application (Figure 3). $L^{*}$ value, which indicates the lightness, gradually declined $(\mathrm{p}<0.05)$ in control sample when storage time elapsed and similar trend was found in $15 \% \mathrm{CO}_{2}-1 \mathrm{~h}$ treated sample but a sudden increase was occurred at the end of the storage . However, $L^{*}$ values were almost maintained in other $\mathrm{CO}_{2}$ treated samples although insignificant inclining or declining fluctuations were observed. Similarly, Zheng et al. [21] also found no significant variation of $L^{*}$ value during storage of strawberry. No remarkable change was observed in $a^{*}$ and chroma values among the treatments and insignificant increasing, decreasing or maintaining patterns were recorded (Figure 3). Sample treated with $15 \% \mathrm{CO}_{2}-3 \mathrm{~h}$ condition showed nearly constant $a^{*}$ and chroma values throughout the storage. Increases in redness (higher $a^{*}$ value) is a general pattern observed during storage of mature strawberry owed to the ripening process which fall after certain period [22]. Since we used about 3/4 portions matured (red color) strawberry, these results may imply that color of strawberry was maintained in the selected storage condition. Our results also suggest that postharvest application of $\mathrm{CO}_{2}$ did not affect the color of strawberry. In agreement with our result, Shin et al. [19] found no variation in Hunter $L^{*}, a^{*}$ and $b^{*}$ values in 'Goha' strawberry during storage. It was also reported that skin color of strawberry was not markedly affected by treatments with different concentration of $\mathrm{CO}_{2}[1]$.

\subsection{Sensory Quality}

Using a nine-point scoring method, overall quality, appearance and visual texture were evaluated on each evaluation day. Sensory scores of these three parameters decreased gradually with the increases in storage time in all treatments (Table 1). Although samples of different treatments received marketable scores until 6 days of storage, interestingly only sample treated with $15 \% \mathrm{CO}_{2}$ for $3 \mathrm{~h}$ yielded slightly higher value to the marketable limit set at 6 in a 9-point scale on 9 days of storage. Among other treatments, $15 \% \mathrm{CO}_{2}-3 \mathrm{~h}$ showed the highest visual and appearance quality on 6 days of storage which were not maintained in later stages. Sample treated with $15 \% \mathrm{CO}_{2}-3 \mathrm{~h}$ also showed comparatively higher values of appearance and visual texture until 9 days of storage. Consequently, we recorded an insignificant $(\mathrm{p}>0.05)$ lower value of softening index in this sample among the treatments on 9 days of storage (Table 1). This result suggests that there is a correlation between softening index and overall quality of strawberry during storage. In many cases, softening is the first visual indication of the deterioration of strawberry quality rather than decay or calyx discoloration or changes in surface color. However, there was no difference among the treatments in either of the sensory parameters on 13 days of storage regardless of treatment condition. It seems that shelf-life of "Goha" strawberry ends near about 9 days. Although we observed greater increase in firmness (measured instrumentally) of $50 \% \mathrm{CO}_{2}$ treated strawberry throughout the storage, sensory quality of those samples were not consistent with firmness values. This result indicates that $\mathrm{CO}_{2}$ not only affect the firmness properties of strawberry, but also affect other biochemical properties that substantially influence sensory qualities. Suppakul et al. [23] reported that high levels of carbon dioxide can induce changes in taste of strawberry and develop undesirable anaerobic glycosis in fruit. In consistence with our sensory results, Shin et al. [19] also found 9 days marketable limit of "Goha" strawberry with different treatments over its untreated control. 

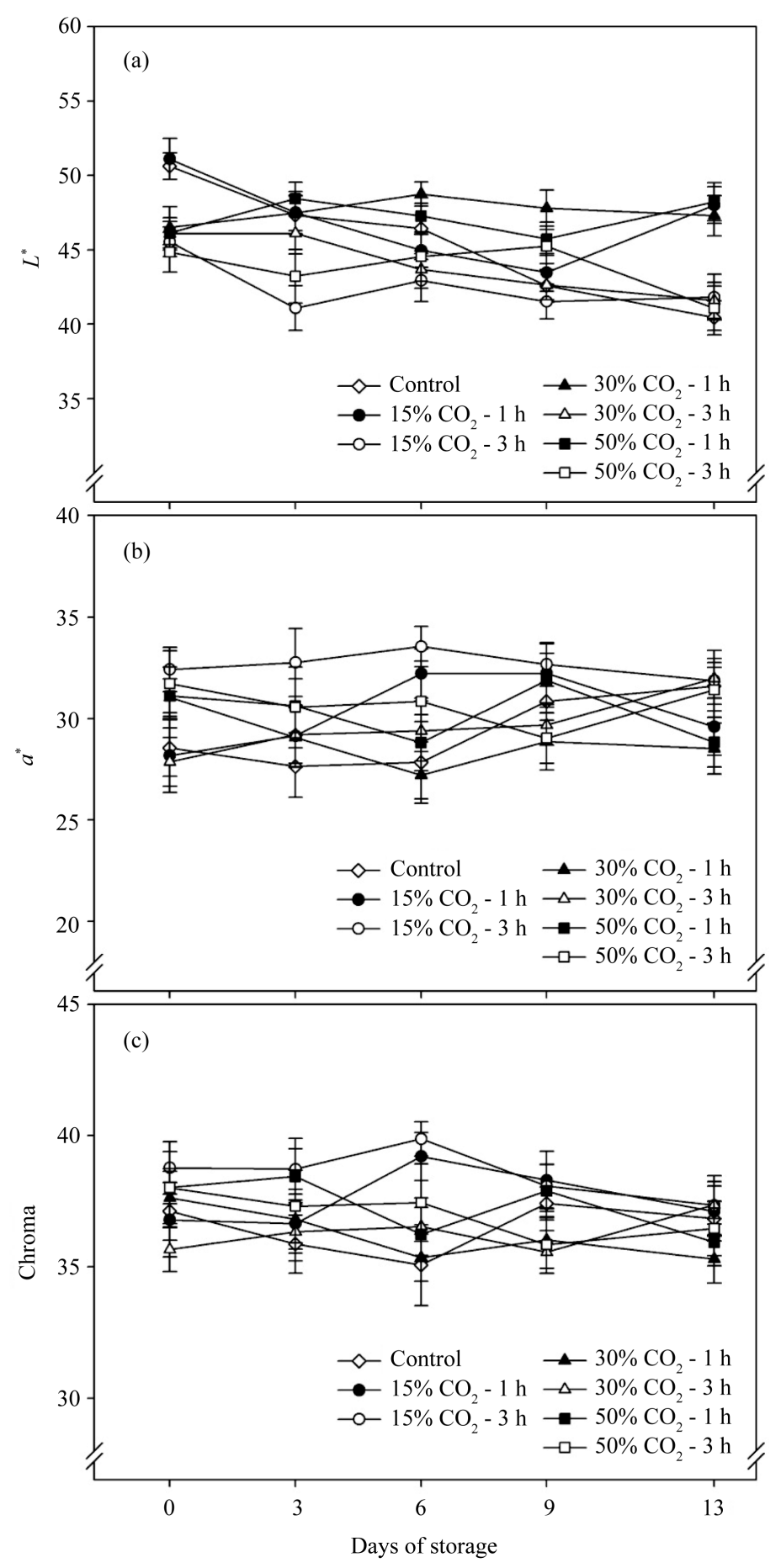

Figure 3. Changes in color parameters measured as $L^{*}$ or lightness (a), $a^{*}$ or redness (b) and chroma (c) of "Goha” strawberry treated with different conditions of $\mathrm{CO}_{2}$ during storage at $4^{\circ} \mathrm{C}$.

\section{Conclusion}

The firmness quality of summer strawberry "Goha” could be increased by $\mathrm{CO}_{2}$ treatment. However, higher doses of $\mathrm{CO}_{2}$ treatment may not ensure other quality parameters other than firmness. We observed that lower concentration but longer duration of $\mathrm{CO}_{2}$ treatment resulted better in maintaining quality than that of higher concentration 
Table 1. Sensory evaluation of 'Goha; strawberry fruit during storage at $4{ }^{\circ} \mathrm{C}$ after treated with different conditions of $\mathrm{CO}_{2}$.

\begin{tabular}{|c|c|c|c|c|c|c|}
\hline \multirow{2}{*}{$\begin{array}{c}\text { Sensory } \\
\text { parameter }\end{array}$} & \multirow{2}{*}{ Treatment } & \multicolumn{5}{|c|}{ Storage day } \\
\hline & & 0 & 3 & 6 & 9 & 13 \\
\hline \multirow{7}{*}{ Overall quality } & Control & $9.00 \pm 0.00^{\mathrm{Aa}}$ & $7.60 \pm 0.22^{\mathrm{ABb}}$ & $6.37 \pm 0.34^{\mathrm{Ac}}$ & $5.47 \pm 0.17^{\mathrm{Bd}}$ & $4.00 \pm 0.44^{\mathrm{Ae}}$ \\
\hline & $15 \% \mathrm{CO}_{2}-1 \mathrm{~h}$ & $9.00 \pm 0.00^{\mathrm{Aa}}$ & $6.87 \pm 0.27^{\mathrm{Bb}}$ & $5.96 \pm 0.23^{\mathrm{Ac}}$ & $5.20 \pm 0.27^{\mathrm{BC}}$ & $4.06 \pm 0.41^{\mathrm{Ad}}$ \\
\hline & $15 \% \mathrm{CO}_{2}-3 \mathrm{~h}$ & $9.00 \pm 0.00^{\mathrm{Aa}}$ & $7.80 \pm 0.27^{\mathrm{ABb}}$ & $6.67 \pm 0.44^{\mathrm{Ac}}$ & $6.53 \pm 0.36^{\mathrm{Ac}}$ & $4.20 \pm 0.56^{\mathrm{Ad}}$ \\
\hline & $30 \% \mathrm{CO}_{2}-1 \mathrm{~h}$ & $9.00 \pm 0.00^{\mathrm{Aa}}$ & $7.27 \pm 0.39^{\mathrm{ABb}}$ & $5.89 \pm 0.55^{\mathrm{Ac}}$ & $5.13 \pm 0.56^{\mathrm{Bcd}}$ & $4.27 \pm 0.42^{\mathrm{Ad}}$ \\
\hline & $30 \% \mathrm{CO}_{2}-3 \mathrm{~h}$ & $9.00 \pm 0.00^{\mathrm{Aa}}$ & $7.20 \pm 0.29^{\mathrm{ABb}}$ & $7.00 \pm 0.32^{\mathrm{Ab}}$ & $5.19 \pm 0.30^{\mathrm{Bc}}$ & $4.53 \pm 0.17^{\mathrm{Ac}}$ \\
\hline & $50 \% \mathrm{CO}_{2}-1 \mathrm{~h}$ & $9.00 \pm 0.00^{\mathrm{Aa}}$ & $6.86 \pm 0.43^{\mathrm{Bb}}$ & $6.13 \pm 0.39^{\mathrm{Ab}}$ & $4.93 \pm 0.29^{\mathrm{Bc}}$ & $4.07 \pm 0.47^{\mathrm{Ac}}$ \\
\hline & $50 \% \mathrm{CO}_{2}-3 \mathrm{~h}$ & $9.00 \pm 0.00^{\mathrm{Aa}}$ & $8.00 \pm 0.28^{\mathrm{Ab}}$ & $6.13 \pm 0.37^{\mathrm{Ac}}$ & $5.79 \pm 0.30^{\mathrm{ABC}}$ & $4.26 \pm 0.16^{\mathrm{Ad}}$ \\
\hline \multirow{7}{*}{ Appearance } & Control & $9.00 \pm 0.00^{\mathrm{Aa}}$ & $7.47 \pm 0.23^{\mathrm{ABb}}$ & $6.73 \pm 0.30^{\mathrm{Ab}}$ & $5.34 \pm 0.35^{\mathrm{ABC}}$ & $3.32 \pm 0.30^{\mathrm{Ad}}$ \\
\hline & $15 \% \mathrm{CO}_{2}-1 \mathrm{~h}$ & $9.00 \pm 0.00^{\mathrm{Aa}}$ & $6.87 \pm 0.27^{\mathrm{Bb}}$ & $6.13 \pm 0.13^{\mathrm{Ac}}$ & $5.00 \pm 0.18^{\mathrm{Bd}}$ & $3.68 \pm 0.29^{\mathrm{Ae}}$ \\
\hline & $15 \% \mathrm{CO}_{2}-3 \mathrm{~h}$ & $9.00 \pm 0.00^{\mathrm{Aa}}$ & $8.20 \pm 0.34^{\mathrm{Ab}}$ & $6.93 \pm 0.34^{\mathrm{Ab}}$ & $6.24 \pm 0.48^{\mathrm{Ab}}$ & $3.87 \pm 0.61^{\mathrm{Ac}}$ \\
\hline & $30 \% \mathrm{CO}_{2}-1 \mathrm{~h}$ & $9.00 \pm 0.00^{\mathrm{Aa}}$ & $7.53 \pm 0.40^{\mathrm{ABb}}$ & $6.33 \pm 0.38^{\mathrm{Ac}}$ & $5.46 \pm 0.43^{\mathrm{ABC}}$ & $4.19 \pm 0.33^{\mathrm{Ad}}$ \\
\hline & $30 \% \mathrm{CO}_{2}-3 \mathrm{~h}$ & $9.00 \pm 0.00^{\mathrm{Aa}}$ & $7.67 \pm 0.35^{\mathrm{ABb}}$ & $7.13 \pm 0.40^{\mathrm{Ab}}$ & $5.07 \pm 0.47^{\mathrm{Bc}}$ & $4.34 \pm 0.20^{\mathrm{Ac}}$ \\
\hline & $50 \% \mathrm{CO}_{2}-1 \mathrm{~h}$ & $9.00 \pm 0.00^{\mathrm{Aa}}$ & $7.47 \pm 0.40^{\mathrm{ABb}}$ & $6.07 \pm 0.25^{\mathrm{Ac}}$ & $4.85 \pm 0.26^{\mathrm{Bd}}$ & $3.57 \pm 0.11^{\mathrm{Ae}}$ \\
\hline & $50 \% \mathrm{CO}_{2}-3 \mathrm{~h}$ & $9.00 \pm 0.00^{\mathrm{Aa}}$ & $7.60 \pm 0.41^{\mathrm{ABb}}$ & $6.42 \pm 0.47^{\mathrm{Ac}}$ & $5.50 \pm 0.31^{\mathrm{ABC}}$ & $3.85 \pm 0.24^{\mathrm{Ad}}$ \\
\hline \multirow{7}{*}{ Visual texture } & Control & $9.00 \pm 0.00^{\mathrm{Aa}}$ & $7.00 \pm 0.37^{\mathrm{Bb}}$ & $6.89 \pm 0.26^{\mathrm{Ab}}$ & $5.93 \pm 0.19^{\mathrm{ABC}}$ & $3.34 \pm 0.22^{\mathrm{Bd}}$ \\
\hline & $15 \% \mathrm{CO}_{2}-1 \mathrm{~h}$ & $9.00 \pm 0.00^{\mathrm{Aa}}$ & $7.20 \pm 0.33^{\mathrm{Bb}}$ & $5.87 \pm 0.20^{\mathrm{Ac}}$ & $4.80 \pm 0.25^{\mathrm{Cd}}$ & $3.36 \pm 0.21^{\mathrm{Be}}$ \\
\hline & $15 \% \mathrm{CO}_{2}-3 \mathrm{~h}$ & $9.00 \pm 0.00^{\mathrm{Aa}}$ & $8.20 \pm 0.08^{\mathrm{Aa}}$ & $6.67 \pm 0.37^{\mathrm{Ab}}$ & $6.19 \pm 0.31^{\mathrm{Ab}}$ & $3.77 \pm 0.44^{\mathrm{ABc}}$ \\
\hline & $30 \% \mathrm{CO}_{2}-1 \mathrm{~h}$ & $9.00 \pm 0.00^{\mathrm{Aa}}$ & $7.27 \pm 0.29^{\mathrm{Db}}$ & $5.93 \pm 0.45^{\mathrm{Ac}}$ & $4.87 \pm 0.36^{\mathrm{Cd}}$ & $4.21 \pm 0.40^{\mathrm{ABd}}$ \\
\hline & $30 \% \mathrm{CO}_{2}-3 \mathrm{~h}$ & $9.00 \pm 0.00^{\mathrm{Aa}}$ & $7.53 \pm 0.13^{\mathrm{ABb}}$ & $6.67 \pm 0.30^{\mathrm{Ac}}$ & $4.87 \pm 0.31^{\mathrm{Cd}}$ & $4.53 \pm 0.17^{\mathrm{Ad}}$ \\
\hline & $50 \% \mathrm{CO}_{2}-1 \mathrm{~h}$ & $9.00 \pm 0.00^{\mathrm{Aa}}$ & $7.40 \pm 0.24^{\mathrm{Bb}}$ & $6.07 \pm 0.34^{\mathrm{Ac}}$ & $4.85 \pm 0.26^{\mathrm{Cd}}$ & $3.89 \pm 0.28^{\text {Abe }}$ \\
\hline & $50 \% \mathrm{CO}_{2}-3 \mathrm{~h}$ & $9.00 \pm 0.00^{\mathrm{Aa}}$ & $7.33 \pm 0.15^{\mathrm{Bb}}$ & $5.87 \pm 0.39^{\mathrm{Ac}}$ & $5.27 \pm 0.25^{\mathrm{BCc}}$ & $3.87 \pm 0.28^{\mathrm{ABd}}$ \\
\hline \multirow{7}{*}{ Softening index } & Control & $0.00 \pm 0.00^{\mathrm{Ad}}$ & $0.17 \pm 0.04^{\mathrm{ABCC}}$ & $0.20 \pm 0.04^{\mathrm{Bc}}$ & $0.34 \pm 0.03^{\mathrm{ABb}}$ & $0.68 \pm 0.01^{\text {Aa }}$ \\
\hline & $15 \% \mathrm{CO}_{2}-1 \mathrm{~h}$ & $0.00 \pm 0.00^{\mathrm{Ac}}$ & $0.20 \pm 0.03^{\mathrm{ABb}}$ & $0.22 \pm 0.05^{\mathrm{Bb}}$ & $0.27 \pm 0.03^{\mathrm{ABb}}$ & $0.57 \pm 0.03^{\mathrm{Aa}}$ \\
\hline & $15 \% \mathrm{CO}_{2}-3 \mathrm{~h}$ & $0.00 \pm 0.00^{\mathrm{Ac}}$ & $0.20 \pm 0.02^{\mathrm{ABb}}$ & $0.21 \pm 0.04^{\mathrm{Bb}}$ & $0.24 \pm 0.03^{\mathrm{Bb}}$ & $0.57 \pm 0.06^{\mathrm{Aa}}$ \\
\hline & $30 \% \mathrm{CO}_{2}-1 \mathrm{~h}$ & $0.00 \pm 0.00^{\mathrm{Ac}}$ & $0.23 \pm 0.03^{\mathrm{Ab}}$ & $0.23 \pm 0.02^{\mathrm{Bb}}$ & $0.26 \pm 0.03^{\mathrm{ABb}}$ & $0.59 \pm 0.06^{\mathrm{Aa}}$ \\
\hline & $30 \% \mathrm{CO}_{2}-3 \mathrm{~h}$ & $0.00 \pm 0.00^{\mathrm{Ae}}$ & $0.11 \pm 0.01^{\mathrm{Cd}}$ & $0.18 \pm 0.03^{\mathrm{Bc}}$ & $0.28 \pm 0.04^{\mathrm{ABb}}$ & $0.60 \pm 0.02^{\mathrm{Aa}}$ \\
\hline & $50 \% \mathrm{CO}_{2}-1 \mathrm{~h}$ & $0.00 \pm 0.00^{\mathrm{Ae}}$ & $0.14 \pm 0.02^{\mathrm{BCd}}$ & $0.24 \pm 0.03^{\mathrm{Bc}}$ & $0.36 \pm 0.05^{\mathrm{Ab}}$ & $0.62 \pm 0.04^{\mathrm{Aa}}$ \\
\hline & $50 \% \mathrm{CO}_{2}-3 \mathrm{~h}$ & $0.00 \pm 0.00^{\mathrm{Ad}}$ & $0.16 \pm 0.01^{\mathrm{ABCC}}$ & $0.39 \pm 0.05^{\mathrm{Ab}}$ & $0.41 \pm 0.02^{\mathrm{ABb}}$ & $0.56 \pm 0.02^{\mathrm{Aa}}$ \\
\hline
\end{tabular}

${ }^{\mathrm{A}-\mathrm{D}}$ Mean values with different letters within a column are significantly different by Duncan's multiple range test at $\mathrm{p}<0.05$; ${ }^{\text {a-e }}$ Mean values with different letters within a row are significantly different by Duncan's multiple range test at $\mathrm{p}<0.05$.

of $\mathrm{CO}_{2}$ treatments. Based on our results, we conclude that $15 \% \mathrm{CO}_{2}$ for $3 \mathrm{~h}$ treatment could provide some beneficial effects during storage of strawberry for certain period.

\section{Acknowledgements}

This work was supported by the ICT R\&D Program of Ministry of Science, ICT and Future Planning (I011414-1016, Intelligent Management of Produce Distribution for Export), Republic of Korea and by the Creative Vitamin Project. 


\section{References}

[1] Gil, M.I., Holcroft, D.M. and Kader, A.A. (1997) Changes in Strawberry Anthocyanins and Other Polyphenols in Response to Carbon Dioxide Treatments. Journal of Agricultural and Food Chemistry, 45, 1662-1667. http://dx.doi.org/10.1021/jf960675e

[2] Li, C. and Kader, A.A. (1989) Residual Effects of Controlled Atmospheres on Postharvest Physiology and Quality of Strawberries. Journal of the American Society for Horticultural Science, 114, 405-407.

[3] Ke, D., Goldstein, L., O’Mahony, M. and Kader, A.A. (1991) Effects of Short Term Exposure to Low $\mathrm{O}_{2}$ and High $\mathrm{CO}_{2}$ Atmospheres on Quality Attributes of Strawberries. Journal of Food Science, 56, 50-54. http://dx.doi.org/10.1111/j.1365-2621.1991.tb07973.x

[4] Shamaila, M., Powrie, W.D. and Skura, B.J. (1992) Sensory Evaluation of Strawberry Fruit Stored under Modified Atmosphere Packaging (MAP) by Quantitative Descriptive Analysis. Journal of Food Science, 57, 1168-1184. http://dx.doi.org/10.1111/j.1365-2621.1992.tb11290.x

[5] Watkins, C.B., Manzano-Mendez, J.E., Nock, J.F., Zhang, J.Z. and Maloney, K.E. (1999) Cultivar Variation in Response of Strawberry Fruit to High Carbon Dioxide Treatments. Journal of the Science of Food and Agriculture, 79, 886-890. http://dx.doi.org/10.1002/(SICI)1097-0010(19990501)79:6<886::AID-JSFA303>3.0.CO;2-0

[6] Yamada, M., Taira, S., Ohtsuki, M., Sato, A., Iwanami, H., Yakushiji, H., Wang, R., Yang, Y. and Li., G. (2002) Varietal Differences in the Ease of Astringency Removal by Carbon Dioxide Gas and Ethanol Vapor Treatments among Oriental Astringent Persimmons of Japanese and Chinese Origin. Scientia Horticulturae, 94, 63-72. http://dx.doi.org/10.1016/S0304-4238(01)00367-3

[7] Pesis, E. and Ben-Arie, R. (2006) Involvement of Acetaldehyde and Ethanol Accumulation during Induced Deastringency of Persimmon Fruits. Journal of Food Science, 49, 896-899.

http://dx.doi.org/10.1111/j.1365-2621.1984.tb13236.x

[8] Goto, T., Goto, M., Chachin, K. and Iwata, T. (1996) The Mechanism of the Increase of Firmness in Strawberry Fruit Treated with 100\% $\mathrm{CO}_{2}$. Nippon Shokuhin Kagaku Kogaku Kaishi, 43, 1158-1162. http://dx.doi.org/10.3136/nskkk.43.1158

[9] Hwang, Y.S., Kim, Y.A. and Lee, W.S. (1999) Effect of Postharvest $\mathrm{CO}_{2}$ Application on the Flesh Firmness and Quality in "Nyoho" Strawberries. Journal of Korean Society for Horticultural Science, 40, 179-182.

[10] Lee, J.N., Lee, E.H., Im, J.S., Nam C.W. and Yae, B.W. (2008) Breeding of Ever-Bearing Strawberry “Goha” for Summer Culture. Korean Journal of Horticultural Science and Technology, 26, 413-416.

[11] Azodanlou, R., Darbellay, C., Luisier, J.L., Villettaz, J.C. and Amado, R. (2003) Quality Assessment of Strawberries (Fragaria Species). Journal of Agricultural and Food Chemistry, 51, 715-721. http://dx.doi.org/10.1021/jf0200467

[12] Mitcham, E.J. (2004) Strawberry. In: Gross, K.C., Wang, C.Y. and Saltveit, M.E., Eds., The Commercial Storage of Fruits, Vegetables, and Florist and Nursery Crops, U.S. Department of Agriculture, Agricultural Research Service, Beltsville Area, Agriculture Handbook No. 66. http://www.ba.ars.usda.gov/hb66/index.html

[13] Smith, R.B. and Skog, L.J. (1992) Postharvest Carbon Dioxide Treatment Enhances Firmness of Several Cultivars of Strawberry. HortScience, 27, 420-421.

[14] Matsumoto, K., Hwang, Y.S., Lee, C.H. and Huber, D.J. (2010) Changes in Firmness and Pectic Polysaccharide Solubility in Three Cultivars of Strawberry Fruit Following Short-Term Exposure to High $\mathrm{pCO}_{2}$. Journal of Food Quality, 33, 312-328. http://dx.doi.org/10.1111/j.1745-4557.2010.00319.x

[15] AOAC (Association of Official Agricultural Chemist) (1990) Official Methods of Analysis. AOAC International 12th Edition, Washington DC.

[16] Hwang, Y.S., Min, J.H., Kim, D.Y., Kim, J.G. and Huber, D.J. (2012) Potential Mechanisms Associated with Strawberry Fruit Firmness Increases Mediated by Elevated $\mathrm{pCO}_{2}$. Horticulture, Environment, and Biotechnology, 53, 41-48. http://dx.doi.org/10.1007/s13580-012-0097-0

[17] Pelayo-Zaldivar, C., Abda, J.B., Ebeler, S.E. and Kader, A.A. (2007) Quality and Chemical Changes Associated with Flavor of "Camarosa" Strawberries in Response to a $\mathrm{CO}_{2}$-Enriched Atmosphere. HortScience, 42, 299-303.

[18] Blanch, M., Sanchez-Ballesta, M.T., Escribano, M.I. and Merodio, C. (2012) Water Distribution and Ionic Balance in Response to High $\mathrm{CO}_{2}$ Treatments in Strawberries (Fragaria vesca L. cv. Mara de Bois). Postharvest Biology and Technology, 73, 63-71. http://dx.doi.org/10.1016/j.postharvbio.2012.06.003

[19] Shin, Y.J., Song, H.Y. and Song, K.B. (2012) Effect of a Combined Treatment of Rice Bran Protein Film Packaging with Aqueous Chlorine Dioxide Washing and Ultraviolet-C Irradiation on the Postharvest Quality of “Goha” Strawberries. Journal of Food Engineering, 113, 374-379. http://dx.doi.org/10.1016/j.jfoodeng.2012.07.001

[20] Han, C., Zhao, Y., Leonard, S.W. and Traber, M.G. (2004) Edible Coatings to Improve Storability and Enhance Nutritional Value of Fresh and Frozen Strawberries (Fragaria $\times$ ananassa) and Raspberries (Rubus ideaus). Postharvest Bi- 
ology and Technology, 33, 67-78. http://dx.doi.org/10.1016/j.postharvbio.2004.01.008

[21] Zheng, Y., Wang, S.Y., Wang, C.Y. and Zheng, W. (2007) Changes in Strawberry Phenolics, Anthocyanins, and Antioxidant Capacity in Response to High Oxygen Treatments. LWT-Food Science and Technology, 40, 49-57.

[22] Kim, J.G., Hong, S.S., Jeong, S.T., Kim, Y.B. and Jang, H.S. (1998) Quality Changes of “Yeobong” Strawberry with CA Storage Conditions. Korean Journal of Food Science and Technology, 30, 871-876.

[23] Suppakul, P., Miltz, J., Sonneveld, K. and Bigger, S.W. (2003) Active Packaging Technologies with an Emphasis on Antimicrobial Packaging and Its Applications. Journal of Food Science, 68, 408-420.

http://dx.doi.org/10.1111/j.1365-2621.2003.tb05687.x 